\title{
Relationship between serum pseudocholinesterase and triglycerides in experimentally induced diabetes mellitus in rats
}

\author{
V. Annapurna ${ }^{2}$, I.Senciall ${ }^{2}$, A.J.Davis ${ }^{1,2}$ and K.M. Kutty ${ }^{1,2}$ \\ ${ }^{1}$ Dr. Charles A. Janeway Child Health Centre and \\ ${ }^{2}$ Faculty of Medicine, Memorial University of Newfoundland, St. John's, Newfoundland, Canada
}

Summary. This study was designed to understand the reasons for the increase in serum pseudocholinesterase activity in diabetes mellitus. Streptozotocin-induced diabetic rats were used for the study. Serum pseudocholinesterase activity increased with the induction of diabetes ( 381.5 units/ $1 \pm 11.8$ ) compared to the non-diabetic rats (243.1 units/1 \pm 7.2 ). Serum triglycerides, total low density lipoprotein and glycerol also increased concurrently with the development of diabetes. Insulin treatment of the diabetic rats normalized serum glucose concomitant with the reduction of pseudocholinesterase activity, triglycerides, total low density lipoprotein and glycerol. Heparin injection appeared to activate lipoprotein lipase in the diabetic rats by showing a marked fall in serum triglyceride and total low density lipoprotein levels but not in pseudocholinesterase activity. Administration of tetraisopropylpyrophosphoramide a specific pseudocholinesterase inhibitor, inhibited serum and adipose tissue pseudocholinesterase activity by $>80 \%$ and liver $>50 \%$.
Concurrent with the inhibition of pseudocholinesterase activity serum triglyceride, low density lipoprotein and glycerol decreased significantly. In normal rats treatment with tetraisopropylpyrophosphoramide also reduced serum lipoproteins markedly, while glycerol only showed a marginal decrease. Glycerol was used as a marker of adipose tissue lipolysis and total low density lipoprotein which is defined as lipoproteins of density $<1.063$ (LDL + VLDL). Our findings suggest (a) that the increase in serum pseudocholinesterase activity in diabetic rats is due to the overproduction of very low density lipoprotein triglyceride in the liver, and (b) decreased lipolysis in the adipose tissue of the diabetic rats treated with tetraisopropylpyrophosphoramide is accompanied by an inhibition of pseudocholinesterase activity.

Key words: Pseudocholinesterase, diabetes, triglyceride, glycerol, lipoproteins.
Pseudocholinesterase (PChE: EC 3.1.1.8) is an unusual enzyme which has no known cholinesters as biological substrates in the mammalian body [1]. Further, PChE has a ubiquitous distribution and is found mainly in the plasma and to a lesser extent in the adipose tissue, small intestine, smooth muscle cells and others [2]. It is also unclear at the present time what the biological inducers of this enzyme are. However, PChE is found to be increased in a significant number of patients with hyperlipoproteinaemia [3, 4] and obesity [5]. The increase in serum PChE is more common in patients with types IIb and IV hyperlipoproteinaemia $[6,7]$.

These observations have been extended in animal models. For example, Zucker fat rats that exhibit a marked increase in very low density lipoprotein (VLDL) have increased serum PChE activity [8]. Besides, genetically obese hyperglycaemic mice (ob/ob) and diabetic $(\mathrm{db} / \mathrm{db})$ mice also have increased serum PChE activity [9].
The common features of these animals are that they are hyperphagic, have increased lipogenesis and synthesize more triglycerides and VLDL [10].

Both Type 1 (insulin-dependent) and Type 2 (non-insulin-dependent) diabetes mellitus in humans are associated with hyperlipoproteinaemia [11] especially when hyperglycaemia is uncontrolled. The major abnormality in lipoprotein metabolism appears to be associated with both increased serum VLDL and triglycerides (TG) and hypertriglyceridaemia. Diabetic patients also exhibit increased levels of serum PChE [12] which may also be related to abnormal lipid metabolism. Alloxan-induced diabetic rats have also been reported to have increased serum PChE activity concomitant with hyperlipoproteinaemia [13].

The objective of the present study was to discover the reasons for the increase in serum PChE activity in diabetes mellitus using the streptozotocin-induced diabetic rat as a model. 


\section{Materials and methods}

Male Sprague Dawley rats weighing 200-250 g were used for all the experiments. The animals were housed in individual cages in a controlled atmosphere at the Animal Care Unit of the Health Science Centre, Memorial University of Newfoundland. All the animals had free access to food and water unless otherwise mentioned. The blood from the experimental rats was collected after an overnight fast to prevent interference from chylomicron TG. Polyacrylamide gel electrophoresis confirmed the absence of chylomicrons in the experimental rats. Hence, TG represents VLDL-TG unless otherwise mentioned. Serial blood samples were collected by cardiac puncture under mild anaesthesia with Ethrane (2-Chloro-1,1,2-trifluoroethyl difluoromethyl ether). Serum was used for all the measurements described below. Diabetes was induced by a single intraperitoneal injection of freshly prepared streptozotocin $(100 \mathrm{mg} / \mathrm{kg}$ body weight) dissolved in $0.01 \mathrm{~mol} / \mathrm{l}$ disodium citrate buffer $\mathrm{pH} 4.5$ [14]. Diabetes was controlled by the administration of 3 IU of protamine zinc insulin/day for one week. The higher dose of tetraisopropylpyrophosphoramide (iso-OMPA) i. e. $17.6 \mathrm{mg} / \mathrm{rat}$ was used to obtain PChE inhibition $>90 \%$. The duration of six days treatment was selected to approximate the time scale used in our previous study [1]. The other seven diabetic rats were given about half of the higher dose to obtain an idea of the dose response effect at a lower dose of iso-OMPA.

Serum PChE was measured with butyrylthiocholine iodide as the substrate and 5,5'di-thiobis-(2-nitrobenzoic acid) (DTNB) as the colouring agent as described by Dietz [15]. Serum triglyceride (TG) [16] and cholesterol [17] were determined using enzymatic methods in a discrete analyser (Monarch - Spokane, Wash. USA). Serum total low density lipoprotein (TLDL) was measured by a turbidimetric procedure using manganese chloride and heparin at $660 \mathrm{~nm}$ [18]. This measures the apo-B containing lipoproteins such as LDL and VLDL in the serum. Serum lipoprotein fractions were monitored using polyacrylamide gel electrophoresis [19]. HDL cholesterol (HDL-C) was estimated after precipitation with phosphotungstic acid and magnesium chloride and measurement of the cholesterol in the supernatant after centrifugation [17]. The degree of adipose tissue lipolysis was monitored by measuring serum glycerol using an enzymatic procedure [Glycerol measured on the Monarch 2000 chemistry autoanalyzer using Test-Combination Triglycerides Kit (cat \# 125032), Boehringer Mannheim GmbH Diagnostica Kit.]. Liver and adipose tissue $\mathrm{PChE}$ was measured as described earlier [8]. For the measurement of liver TG, lipids were extracted using chloroform/methanol (2:1) [20] and the TG in the extract was estimated as described for the serum by employing the manual technique $[16]$.

The measure of the precision of the methods used in this study in terms of mean \pm standard deviation (SD) and coefficient of variation (CV) was monitored using the quality control serum "Precilip" (Boehringer Mannheim GmbH, Mannheim, FRG). Day-to-day variation calculated over a period of one month for the analytes are as follows. Cholesterol (4.06 mmol/ $\pm 0.15 \mathrm{SD}, \mathrm{CV} 3.6 \%) \mathrm{TG}$ $(2.3 \mathrm{mmol} / \mathrm{l} \pm 0.08, \mathrm{CV} 3.27 \%)$, HDL Cholesterol $(1.68 \mathrm{mmol} / 1$ $\pm 0.07, \mathrm{CV} 4.23 \%)$, total LDL $(1.77 \mathrm{~g} / \pm 0.12, \mathrm{CV} 6.8 \%)$, glycerol $(1.64 \mathrm{mmol} / \mathrm{l} \pm 0.07, \mathrm{CV} 5.26 \%)$ and $\mathrm{PChE}(2175$ units $\pm 65, \mathrm{CV}$ $2.98 \%$ ).

\section{Statistical analysis}

Results are presented as mean \pm SEM. The statistical analysis was done using the Student's $t$-test.

\section{Results}

\section{Induction of diabetes with streptozotocin}

Table 1 shows a comparison of serum and tissue values in rats before and after the induction of diabetes with streptozotocin. The reduced number of rats in the diabetic
Table 1. Comparison of serum values before and $72 \mathrm{~h}$ after streptozotocin-induced-diabetes in rats

\begin{tabular}{lcc}
\hline Variables & $\begin{array}{c}\text { Before induction } \\
(n=38)\end{array}$ & $\begin{array}{l}\text { After induction } \\
(n=30)\end{array}$ \\
\hline Glucose $(\mathrm{mmol} / \mathrm{l})$ & $5.09 \pm 0.21$ & $27.7 \pm 1.334^{\mathrm{a}}$ \\
PChE $(\mathrm{units} / \mathrm{l})$ & $243.1 \pm 7.2$ & $381.5 \pm 11.8^{\mathrm{a}}$ \\
TG $(\mathrm{mmol} / \mathrm{l})$ & $0.63 \pm 0.05$ & $2.43 \pm 0.24^{\mathrm{a}}$ \\
Glycerol $(\mathrm{mmol} / \mathrm{l})$ & $0.33 \pm 0.01$ & $0.52 \pm 0.03^{\mathrm{a}}$ \\
Chol $(\mathrm{mmol} / \mathrm{l})$ & $1.62 \pm 0.06$ & $1.58 \pm 0.09^{\mathrm{b}}$ \\
TLDL $(\mathrm{g} / \mathrm{l})$ & $0.17 \pm 0.01$ & $0.27 \pm 0.02^{\mathrm{a}}$ \\
HDL-C (mmol/l) & $1.4 \pm 0.07$ & $1.19 \pm 0.07^{\mathrm{a}}$ \\
Weight $(\mathrm{g})$ & $259 \pm 1.49$ & $229.7 \pm 1.36^{\mathrm{a}}$ \\
\hline
\end{tabular}

$n=$ Number of animals; PChE $=$ Pseudocholinesterase, $\mathrm{TG}=$ Triglycerides, Chol $=$ Cholesterol, TLDL $=$ Total low density lipoprotein, HDL-C = High density lipoprotein cholesterol ${ }^{\mathrm{a}} \mathrm{p}<0.05 ;{ }^{\mathrm{b}}$ not significant

group is a result of rats that died after streptozotocin injection. Diabetes was induced by a single intraperitoneal injection of streptozotocin $(100 \mathrm{mg} / \mathrm{kg}$ body weight). Induction of diabetes was established by qualitative test of urine for glucosuria. A significant increase in serum glucose and PChE was noted within $72 \mathrm{~h}$ of streptozotocin treatment with a concomitant increase in TG, glycerol and TLDL levels. There was no significant change in the serum cholesterol concentration, while the decrease in HDL-C was significant $(p<0.05)$. A decrease of $12 \%$ in the average body weight was noted in streptozotocin-treated rats.

\section{The influence of insulin treatment and withdrawal on diabetic rats}

Figure 1 illustrates the effect of insulin treatment and withdrawal on diabetic rats. The diabetic rats were given 3 IU s.c. insulin/day for one week. Treatment of diabetic rats with insulin resulted in a significant decrease in the serum level of glucose $(p<0.001)$.

With the diabetes under control, serum levels of PChE, glycerol and TG decreased significantly $(p<0.05)$ while there was no significant change in the TLDL concentration. In contrast cholesterol and HDL-C showed a significant increase $(p<0.05)$. Glucosuria reappeared when insulin treatment was discontinued. The levels of serum glucose, TG, glycerol, PChE, cholesterol, TLDL and HDL-C reverted to those observed in the diabetic state, when measured at the end of the third day after stopping the insulin treatment.

\section{Effect of heparin treatment of the diabetic rats}

Table 2 shows the effect of heparin treatment on serum PChE activity, TG, cholesterol, glucose, HDL-C and TLDL levels. Heparin was injected (500 U) through the tail vein and blood was collected (as before) $30 \mathrm{~min}$ after the injection. In the heparin-treated animals serum TG showed a significant $(p<0.001)$ reduction but the treatment did not affect PChE activity, LDL and cholesterol levels (Table 2). A non-significant rise in serum glucose 

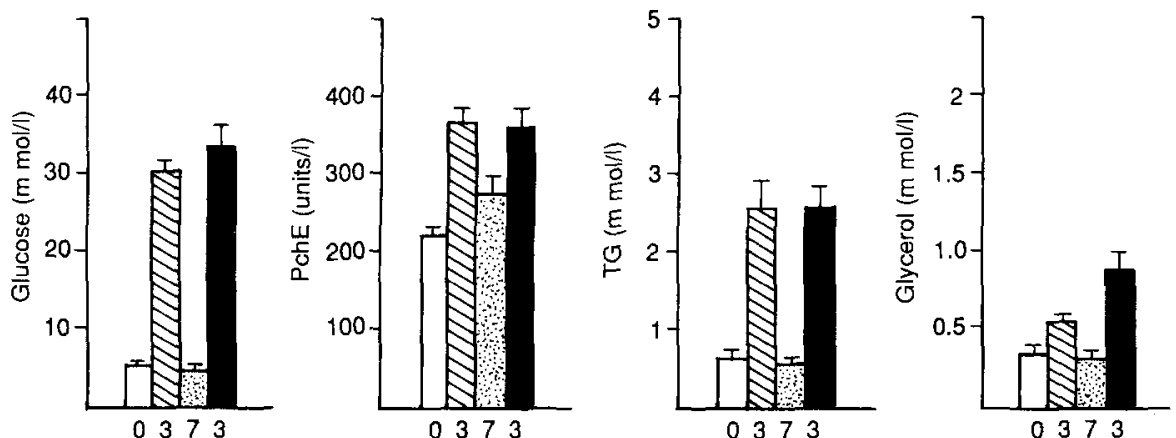

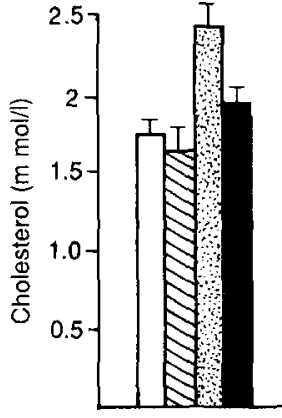

0373

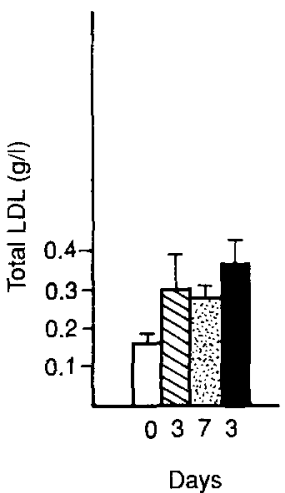

Days

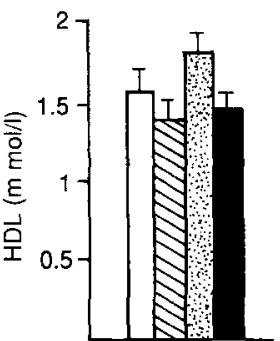

0373
Fig. 1. The mean \pm SEM of the variables (y-axis) and time intervals ( $\mathrm{x}$-axis) among rats under different treatment conditions; non-diabetic rats $(n=12) 3$ days after the injection of streptozotocin $(n=12)$ ( 7 days after the treatment of the diabetic rats with insulin $(n=8)(\rightarrow)$, and 3 days after the withdrawal of insulin treatment $(n=6)(\boldsymbol{m})$. Abbreviations as in Table 1. ( $n$ represents the number of rats) was observed $(p<0.630)$. Administration of an equal volume of $\mathrm{NaCl}(0.15 \mathrm{~mol} / \mathrm{l})$ dissolved in sterile distilled water to the diabetic rats had no effect on serum PChE activity or lipid levels. However, serum glucose showed a small but significant increase $(p<0.05)$.

\section{Effect of iso-OMPA treatment of diabetic and normal rats}

Two dose levels (17.6 and $8.3 \mathrm{mg} / \mathrm{rat}$ ) of iso-OMPA (tetraisopropyl pyrophosphoramide), a specific PChE inhibitor was administered to the diabetic rats intraperitoneally for a period of 6 days. This was to determine whether the inhibition of PChE activity in general and specifically in the adipose tissue can decrease lipolysis and thereby reduce the efflux of fatty acids necessary for the synthesis of TG and VLDL. Treatment of the diabetic rats with iso-OMPA (Table 3) at both the higher dose

Table 2. Comparison of the serum variables (units of measure as in Table 1) between untreated diabetic rats vs control rats, heparintreated diabetic rats vs untreated diabetic rats, and diabetic rats treated with $\mathrm{NaCl}(0.15 \mathrm{~mol} / \mathrm{l})$ vs untreated diabetic rats

\begin{tabular}{lccccc}
\hline Variables & $\begin{array}{l}\text { Control } \\
\text { rats } \\
(n=10)\end{array}$ & $\begin{array}{l}\text { Untreated } \\
\text { diabetic } \\
\text { rats } \\
(n=10)\end{array}$ & \begin{tabular}{l} 
Treated diabetic rats \\
\cline { 3 - 7 }
\end{tabular} & $\begin{array}{l}\text { Heparin } \\
(n=5)\end{array}$ & $\begin{array}{l}\mathrm{NaCl} \\
(n=5)\end{array}$ \\
\hline Glucose & $6.34 \pm 0.33$ & $29.81 \pm 1.66^{\mathrm{a}}$ & $31.12 \pm 2.06^{\mathrm{c}}$ & $35.84 \pm 1.69^{\mathrm{b}}$ \\
PChE & $231.6 \pm 18.8$ & $417.0 \pm 26.7^{\mathrm{a}}$ & $407.4 \pm 292^{\mathrm{c}}$ & $420.8 \pm 41.5^{\mathrm{c}}$ \\
TG & $0.79 \pm 0.08$ & $4.47 \pm 0.8^{\mathrm{a}}$ & $0.65 \pm 0.17^{\mathrm{a}}$ & $5.67 \pm 1.54^{\mathrm{c}}$ \\
Chol & $1.71 \pm 0.11$ & $1.83 \pm 0.17^{\mathrm{c}}$ & $1.59 \pm 0.18^{\mathrm{c}}$ & $1.79 \pm 0.13^{\mathrm{c}}$ \\
HDL-C & $1.33 \pm 0.08$ & $1.13 \pm 0.08^{\mathrm{c}}$ & $1.04 \pm 0.1^{\mathrm{c}}$ & $1.07 \pm 0.14^{\mathrm{c}}$ \\
TLDL & $0.13 \pm 0.02$ & $0.33 \pm 0.04^{\mathrm{a}}$ & $0.24 \pm 0.06^{\mathrm{c}}$ & $0.36 \pm 0.08^{\mathrm{c}}$ \\
\hline
\end{tabular}

Abbreviations as in Table $1 .{ }^{\mathrm{a}} \mathrm{p}<0.001 ;{ }^{\mathrm{b}} \mathrm{p}<0.05 ;{ }^{\mathrm{c}}$ not significant
(17.6 mg/rat) and lower dose $(8.3 \mathrm{mg} / \mathrm{rat})$ resulted in a significant reduction of serum TG, cholesterol, glycerol and TLDL when compared to the diabetic rats. However, the lower dose of iso-OMPA treatment caused a lesser reduction in the serum levels of TG, cholesterol and TLDL compared to the diabetic rats treated with the higher dose of iso-OMPA. PChE inhibition was significant at both the dose levels of iso-OMPA i.e. $>90 \%$ with the higher dose and $>74 \%$ with the lower dose in the diabetic rats. The higher dose of iso-OMPA also caused a significant reduction in the serum glucose level $(p<0.05)$, while the lower dose had no effect. Table 4 shows the tissue levels of TG and $\mathrm{PChE}$ activity. Liver TG and PChE activity in the liver and adipose tissue were significantly decreased in the isoOMPA-treated rats $(p<0.05)$. The inhibition of PChE activity in the normal rats after treatment with iso-OMPA also resulted in a significant reduction $(p<0.05)$ in the serum glycerol and TG levels (Fig. 2). Liver TG also decreased significantly $(p<0.05)$ in the iso-OMPA-treated normal rats (Table 4).

\section{Discussion}

Treatment of rats with streptozotocin creates a useful experimental model in insulin-dependent diabetes mellitus $[21,22]$ for investigating the relationship between PChE and VLDL. Our results show clearly that serum PChE activity in streptozotocin-induced diabetic rats increases in concert with the development of hyperlipaemia. In general, this model confirms observations in diabetic rats and in patients with hypertriglyceridaemia $[6,13]$.

Insulin deficiency is associated with increased adipose tissue lipolysis [22] which provides the liver with excess 
Table 3. Comparison of the serum variables (units of measure as in Table 1) between untreated diabetic rats vs normal control rats, isoOMPA (higher dose) treated diabetic rats vs untreated diabetic rats and iso-OMPA (lower dose) treated diabetic rats vs untreated diabetic rats

\begin{tabular}{|c|c|c|c|c|}
\hline \multirow[t]{2}{*}{ Variables } & \multirow{2}{*}{$\begin{array}{l}\text { Control } \\
\text { rats } \\
(n=14)\end{array}$} & \multirow{2}{*}{$\begin{array}{l}\text { Untreated } \\
\text { diabetic } \\
\text { rats } \\
(n=14)\end{array}$} & \multicolumn{2}{|c|}{ Treated diabetic rats } \\
\hline & & & $\begin{array}{l}\text { Iso-OMPA } \\
(n=7) \\
(17.6 \mathrm{mg} / \mathrm{rat})\end{array}$ & $\begin{array}{l}\text { Iso-OMPA } \\
(n=7) \\
(8.3 \mathrm{mg} / \text { rat })\end{array}$ \\
\hline Glucose & $4.19 \pm 0.09$ & $32.77 \pm 1.33^{a}$ & $25.88 \pm 1.92^{\mathrm{a}}$ & $32.74 \pm 1.98^{\mathrm{b}}$ \\
\hline PChE & $230 \pm 7.01$ & $440 \pm 18.5^{\mathrm{a}}$ & $35.83 \pm 0.83^{\mathrm{a}}$ & $69.43 \pm 1.94^{\mathrm{a}}$ \\
\hline TG & $0.99 \pm 0.08$ & $4.62 \pm 0.62^{\mathrm{a}}$ & $0.51 \pm 0.08^{\mathrm{a}}$ & $0.62 \pm 0.1^{\mathrm{a}}$ \\
\hline Chol & $1.25 \pm 0.07$ & $1.28 \pm 0.12^{\mathrm{b}}$ & $0.38 \pm 0.09^{a}$ & $0.7 \pm 0.22^{\mathrm{a}}$ \\
\hline Glycerol & $0.32 \pm 0.02$ & $0.72 \pm 0.07^{\mathrm{a}}$ & $0.39 \pm 0.06^{a}$ & $0.37 \pm 0.07^{\mathrm{a}}$ \\
\hline TLDL & $0.12 \pm 0.01$ & $0.56 \pm 0.12^{\mathrm{a}}$ & $0.05 \pm 0.02^{\mathrm{a}}$ & $0.13 \pm 0.02^{a}$ \\
\hline
\end{tabular}

Abbreviations as in Table 1. ISO-OMPA = tetraisopropylpyrophosphoramide ${ }^{a} \mathrm{p}<0.05 ;{ }^{\mathrm{b}}$ not significant

non-esterified fatty acids. The excess fatty acids thus available in diabetes can result in either ketoacidosis and/or increased synthesis of TG [23] which can be reversed with insulin treatment [22]. Insulin treatment of the diabetic rats (Fig.1) caused a parallel reduction in both serum PChE and TG. However, the proportional decrease in TG was far greater than PChE. Insulin is known to activate lipoprotein lipase [22]. Both decreased synthesis and increased clearance could account for the reduction in serum TG in the insulin-treated diabetic rats. However, reduction in serum PChE may be related only to the decreased production of VLDL. Heparin is also known to activate lipoprotein lipase causing rapid clearance of VLDL-TG (27). However, heparin treatment of the diabetic rats (Table 2 ) very rapidly decreased serum TG without affecting the serum $\mathrm{PChE}$ activity. This suggests that the increase in serum PChE activity in diabetic rats is not a function of reduced clearance from the blood in the insulin deficient state but reflects PChE overproduction.

The source of serum PChE is the liver [2] and serum levels may be an indication of its rate of synthesis [24]. However, the hepatic levels of PChE were not elevated in diabetic rats relative to control rats. PChE is a glycoprotein [25] and it is probably exported directly into circulation along with VLDL at a rate matching its synthesis.

Clitherow et al. [28] have suggested that PChE may be involved in hepatic fatty acid metabolism. Other possibilities include a role as a hormone sensitive lipase in rat aorta and adipose tissue $[29,30]$. To determine whether elevated serum PChE had any direct role in VLDL metabolism we treated both normal and diabetic rats with
Table 4. Comparison of the variables in tissues; liver TG, liver and adipose tissue $\mathrm{PChE}$. Control rats vs control rats treated with isoOMPA and diabetic rats. Diabetic rats vs diabetic rats treated with iso-OMPA

\begin{tabular}{|c|c|c|c|c|}
\hline Variables & $\begin{array}{l}\text { Control rats } \\
(n=12)\end{array}$ & $\begin{array}{l}\text { Control rats } \\
\text { treated with } \\
\text { iso-OMPA } \\
(n=6)\end{array}$ & $\begin{array}{l}\text { Diabetic } \\
\text { rats } \\
(n=8)\end{array}$ & $\begin{array}{l}\text { Diabetic rats } \\
\text { treated with } \\
\text { iso-OMPA } \\
(n=7)\end{array}$ \\
\hline $\begin{array}{l}\text { Liver TG }(\mu \mathrm{mol} / \mathrm{g} \\
\text { wet wt })\end{array}$ & $19.9 \pm 0.68$ & $16.9 \pm 0.9^{\mathrm{a}}$ & $23.4 \pm 1.2^{\mathrm{a}}$ & $13.5 \pm 2^{\mathrm{a}}$ \\
\hline 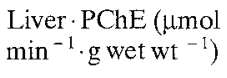 & $0.9 \pm 0.04$ & $0.51 \pm 0.01^{\mathrm{a}}$ & $1.01 \pm 0.03^{\mathrm{b}}$ & ${ }^{b} 0.4 \pm 0.01^{\mathrm{a}}$ \\
\hline $\begin{array}{l}\text { Adipose } \\
\text { tissue PChE } \\
\left(\mu \mathrm{mol} \cdot \min ^{-1}\right. \\
\left.\text { g wet } \mathrm{wt}^{-1}\right)\end{array}$ & $0.35 \pm 0.01$ & $0.04 \pm 0.01^{\mathrm{a}}$ & $0.43 \pm 0.01^{b}$ & $0.13 \pm 0.01^{\mathrm{a}}$ \\
\hline
\end{tabular}

Abbreviations as in Table 1. ISO-OMPA $=$ tetraisopropylpyrophosphoramide ${ }^{\mathrm{a}} \mathrm{p}<0.05 ;{ }^{\mathrm{b}}$ not significant

iso-OMPA, a specific inhibitor of $\mathrm{PChE}$ [31]. We have previously observed (unpublished data) that iso-OMPA decreased adrenaline-mediated lipolysis in isolated rat adipocyte. Our present findings that iso-OMPA significantly decreased serum glycerol suggest that iso-OMPA may have a similar role as an inhibitor of lipolysis in vivo. IsoOMPA-treated diabetic rats exhibited decreased serum and liver TG, suggesting that this anti-PChE blocks the increased fatty acid mobilisation-VLDL synthesis cycle characteristic of diabetes. In the normal rat it does not appear that fatty acids from the adipose tissue contribute significantly to the synthesis of VLDL in the liver. In the normal rat, the serum level of LDL is very low and is known to be derived from VLDL and this transformation is initiated by the action of lipoprotein lipase [32]. Iso-OMPAtreated normal rats showed a marked reduction in TLDL. We had made similar observations in a patient [33] who accidentally ingested an organophosphate (Parathion) anti-cholinesterase and in rats [34] treated with a carbamate (neostigmine) anti-cholinesterase. Parathion and neostigmine inhibit both PChE and acetylcholinesterase.

In conclusion, although the changes in PChE activity and lipid metabolism documented here in diabetic and normal animals are highly suggestive of an important relationship, they are still circumstantial.

Acknowledgements. This study was supported by research funds from the Faculty of Medicine, MUN; The Dr. Charles A. Janeway Child Health Centre and Nutrition Research and Education Foundation of Newfoundland.

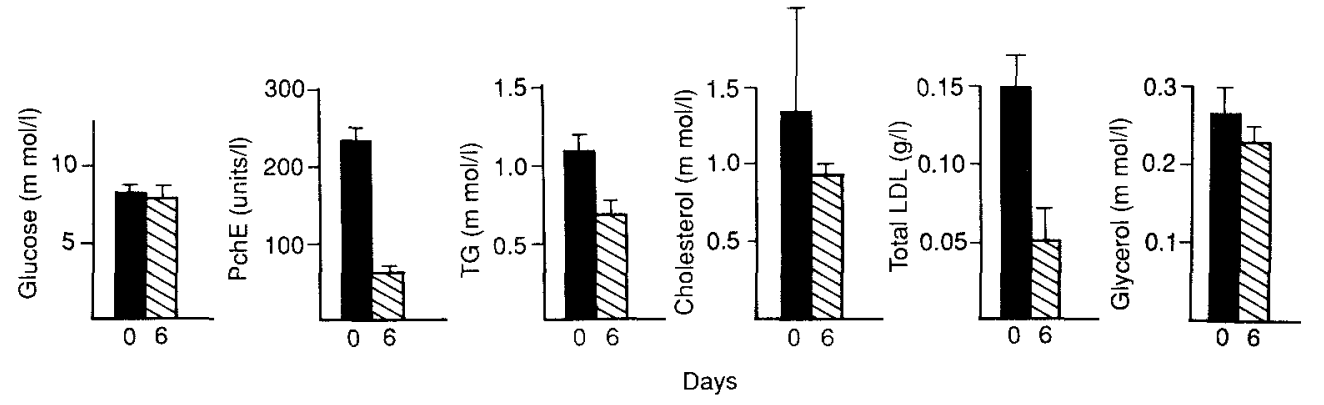

Fig. 2. The effect of tetraisopropylpyrophosphoramide (iso-OMPA) treatment of the serum variables (y-axis) in normal rats before and after treatment $\square$ for 6 days with the phosphocholinesterase inhibitor. The results are the mean \pm SEM. Abbreviations as in Table 1. ( $n$ represents the number of rats) 


\section{References}

1. Kutty KM, Annapurna V, Prabhakaran V (1989) Pseudocholinesterase: a protein with functions unrelated to its name. Biochem Soc Trans 17: 555-556

2. Silver A (1974) The biology of cholinesterases, 1st edn. NorthHolland Publishing, Amsterdam Oxford, pp 443-449

3. Cucuianu M, Popescu TA, Opincaru A, Haragus S (1975) Serum pseudocholinesterase and ceruloplasmin in various types of hyperlipoproteinaemia. Clin Chim Acta 59: 19-27

4. Chu MI, Fontaine P, Kutty KM (1978) Cholinesterase in serum and low density lipoprotein of hyperlipidaemic patients. Clin Chim Acta 85: 55-59

5. Cucuianu M, Popescu TA, Haragus S (1968) Pseudocholinesterase in obese and hyperlipaemic subjects. Clin Chim Acta 22:151155

6. Kutty KM, Jain R, Huang S, Kean K (1981) Pseudocholinesterase/High density lipoprotein cholesterol ratio as an index of risk for cardiovascular disease. Clin Chim Acta 115: 55-61

7. Jain R, Kutty KM, Huang S, Kean K (1983) Pseudocholinesterase/High density lipoprotein cholesterol ratio in serum of normal persons and of hyperlipoproteinaemics. Clin Chem 29: 10311033

8. Kutty KM, Jain R, Kean K, Peper C (1984) Cholinesterase activity in the serum and liver of Zucker fat rats and controls. Nutr Res 4: 99-104

9. Kutty KM, Huang S, Kean K (1981) Pseudocholinesterase in obesity hypercaloric diet induced changes in experimental obese mice. Experientia 37: 1141-1142

10. Schonfeld G, Pfleger B (1971) Overproduction of very low density lipoprotein by liver of genetically obese rats. Am J Physiol 222: $1178-1181$

11. Howard BV (1987) Lipoprotein metabolism in diabetes mellitus. J Lip Res 28: 613-628

12. Antopol W, Tuchman T, Schifrin W (1937) Choline-esterase activity in human serum with special reference to hyperthyroidism. Proc Soc Exp Biol Med 36: 46-49

13. Deshmukh MB (1986) Changes in serum cholinesterase activity and lipoprotein cholesterol levels in rats during diabetes. IRCS Med Sci 14: 234

14. Blackshear PJ, Alberti KGMM (1974) Experimental diabetic ketoacidosis. Sequential changes of metabolic intermediates in blood, liver, CSF and brain after acute insulin deprivation in streptozotocin induced diabetic rats. Biochem J 138: 107-117

15. Dietz AA, Rubinstein MH, Lubrano T (1973) Colourimetric determination of serum cholinesterase and its genetic variants by the propionyl thiocholine-dithiobis (nitrobenzoic acid) procedure. Clin Chem 19: 1309-1313

16. Bucolo G, David H (1973) Quantitative determination of serum triglyceride by the use of enzyme. Clin Chem 19: 476-482

17. Allain CC, Poon LS, Chan CSG, Richmond W, Fu PC (1974) Enzymatic determination of total serum cholesterol. Clin Chem 20: $470-475$

18. Burstein M, Samaille J (1957) Sur la precipitation selective des beta lipoproteins du serum par l'heparine et les heparinoides de synthese en presence du $\mathrm{Cl}_{2} \mathrm{Ca}_{1}$. I Physiol (Paris) 49: 83-86
V.Annapurna et al:: Pseudocholinesterase in experimental diabetes

19. Frings CS, Foster LB, Cohen PS (1971) Electrophoretic separation of serum lipoproteins in polyacrylamide gel. Clin Chem 17: 111-114

20. Folch J, Lees M, Sloane Stanley GH (1957) A simple method for the isolation and purification of total lipids from animal tissues. $J$ Biol Chem 226: 497-509

21. Schein PS, Alberti KGMM, Williamson DH (1971) Effects of streptozotocin on carbohydrate and lipid metabolism in rat. Endocrinology 89: 827-834

22. Schnatz JD, Williams RH (1963) The effect of acute insulin deficiency in rat adipose tissue lipolytic activity and plasma lipids. Diabetes 12: 174-178

23. Nikkila EA, Kekki M (1973) Plasma triglyceride transport kinetics in diabetes mellitus. Metabolism 22: 1-22

24. Brown SS, Kalow W, Pilz W, Whittaker M, Woronick CL (1981) The plasma cholinesterase: a new perspective. Adv Clin Chem 22: $1-123$

25. Das PK, Liddell J (1970) Purification and properties of human serum cholinesterase. Biochem J 116: 875-881

26. Stein O, Stein Y (1967) Lipid synthesis, intracellular transport, storage and secretion. J Cell Biol 33: 319-339

27. Robinson DS, Speake BK (1989) Role of insulin and other hormones in the control of lipoprotein lipase activity. Biochem Soc Trans 17: 40-42

28. Koelle GB, Davis R, Diliberto EJ Jr., Koelle WA (1974) Selective near-total, irreversible inactivation of peripheral pseudocholinesterase and acetylcholinesterase in cats in vivo. Biochem Pharmacol 23: 175-188

29. Clitherow JW, Mitchard M, Harper NJ (1963) The possible biological function of pseudocholinesterase. Nature 199: 1000-1001.

30. Colville K, Salvador R, Lindsay L, Burnes J (1964) Lowering effect of neostigmine on plasma free fatty acid. Nature 204: 888889

31. Szendzikowski S, Patelski J, Pearse A (1961/62) The influence of cholinesterase inhibitors on the lipolytic activity of rat aorta. Enzymol Biol Clin 1: 125-137

32. Eisenberg S, Rachmilewitz D (1973) Metabolism of rat plasma very low density lipoprotein. 1. Fate in circulation of the whole lipoprotein. Biochim Biophys Acta 326: 378-390

33. Kutty KM, Jacob JC, Hutton CJ, Davis PJ, Peterson SC (1975) Serum beta lipoprotein: studies in a patient and in guinea pigs after the ingestion of organophosphorous compounds. Clin Biochem 8: 379-383

34. Kutty KM, Redheendran R, Murphy D (1977) Serum cholinesterase, function in lipoprotein metabolism. Experientia 33: $420-421$

Received: 5 June 1990

and in final revised form: 2 January 1991

Dr. K.M.Kutty

Janeway Child Health Centre

St. John's, Newfoundland AIA IR8

Canada 